\title{
UAV Photogrammetry-based Mapping of the Pocket Beaches of Isola Bella Bay,Taormina (Eastern Sicily)
}

\author{
Anselme Muzirafuti \\ dept. Mathematics, Informatics, Physics \\ and Earth Sciences \\ University of Messina \\ Messina, Italy \\ https://orcid.org/0000-0002-3563-9264 \\ Giovanni Randazzo \\ dept. Mathematics, Informatics, Physics \\ and Earth Sciences \\ University of Messina \\ Messina, Italy \\ grandazzo@unime.it
}

\author{
Maria Cascio \\ dept. Mathematics, Informatics, Physics \\ and Earth Sciences \\ University of Messina \\ Messina, Italy \\ maria.cascio86@gmail.com
}

\author{
Stefania Lanza \\ dept. Mathematics, Informatics, Physics \\ and Earth Sciences \\ University of Messina \\ Messina, Italy \\ stefania.lanza@unime.it
}

\begin{abstract}
Pocket Beach (PB) planview geometry analysis is one of the most important steps needed for PB characterization and dynamic evaluation. With modern technology, quantitative morphology of a PB can be obtained with a high degree of confidence. In this paper we used Unmanned Aerial Vehicle (UAV) photogrammetry-based mapping technology combining drone and Global Positioning System (GPS) for 2D and 3D models' reconstruction of Isola Bella bay PBs located along the coast of the town of Taormina (eastern Sicily).
\end{abstract}

The aim of this paper is to show how very high spatial resolution data can be obtained and analyzed for the retrieval of geomorphological features and geometric parameters of PBs. A computer-assisted visual interpretation approach was adopted to manually digitize, delineate and extract the planform characteristics of the PB. The planview geometry analysis was conducted on orthophotos and digital surface models of $1.81 \mathrm{~cm}$ and $1.69 \mathrm{~cm}$ spatial resolutions, acquired during two flight surveys.

The mapping approach adopted in this paper shows that information on planform geometry of PBs can be obtained faster using modern remote sensing technologies allowing time series analysis of planview parameters.

Keywords-UAV, photogrammetry, Pocket beach, Taormina, georeferencing, planview geometry, remote sensing

\section{INTRODUCTION}

Pocket beaches (PBs), commonly distributed along rocky coasts $[1,2]$, are the beaches controlled by both geological or human structures, such as groins or jetties $[3,4,5]$. In recent years, several detailed studies have been conducted on PBs $[2,5-16]$. PBs have often been described and classified based on geometric indices. These indices are computed based on planview parameters that represent the geometric characteristics of a beach [17].

Planview geometry parameters and morphological characteristics of PBs have been previously studied to determine their sheltering effect and their status of equilibrium; however, the planform measurements have been obtained via laborious fieldwork, orthophotos and wave climate data [9]. With emerging remote sensing technologies $[18,19]$, planview geometry analysis of PBs can be conducted rapidly and efficiently. Such analysis is very important because geometric information provides a better understanding of shoreline dynamics as well as the exposure of PBs to incident waves.

PBs are widespread along the Mediterranean coast [9, 20, 21] and they often represent valuable natural elements; but they are sometimes threatened by the impact of anthropogenic pressure. PBs, both natural and man-made, are widespread along the Sicilian coast and the characteristics of their exceptional natural landscape make them very attractive for tourists. The coast of Sicily has several PBs, with different dimensions and various planform geometries, differently exposed to incident wave energy and with limited sediment sourcing by drainage basin.

Few studies have been conducted to determine the planform configuration of the current shape of the PBs of Sicily. In this study we used Unmanned Aerial Vehicle (UAV) photogrammetry-based mapping technology combining drone and Global Positioning System (GPS) for two- and threedimensional mapping of Isola Bella bay PBs located on the coast of the town of Taormina. The aim of the study is to show how very high spatial resolution data can be obtained and analyzed for the retrieval of geomorphological features and geometric parameters of PBs. A computer-assisted visual interpretation approach was adopted to manually digitize, delineate, and extract the planform characteristics of the PB from orthophotos and digital surface models acquired during two flight surveys; and to compare the results obtained for each PB. This study was conducted within the framework of the BESS project - Pocket Beach Management and Remote Surveillance System Project (BESS), co-financed by the European Union through the Sicilian Region (European Regional Development Fund, Interreg Italy - Malta 20142020), and coordinated by the Department of Mathematical 
and Computer Sciences, Physical Sciences and Earth Sciences (MIFT) of the University of Messina (UNIME). In the BESS project, all Sicilian and Maltese PBs have been studied [11].

\section{MATERIAL AND METHODS}

\section{A. Area of study}

The Isola Bella bay is one of the most important tourist attractions in Sicily, with more than one million visitors preCOVID-19. It is located along the eastern coast of Sicily, in the municipality of Taormina, in the province of Messina. The bay is enclosed between Capo Sant'Andrea, to the north, and Capo Taormina to the south, centrally dominated by Isola Bella itself and its tombolo (Figs. 1,2). Along this sector, from Capo Taormina to Capo San Raineri, on the Ionian side, beaches are wide and discontinuous, composed of coarse sands and fine to coarse cobbles, deriving from the dismantlement of the Peloritani Chain, immediately behind them, which generated fragments of metamorphic and carbonate rocks (gravel - cobble size) and quartz grains (coarse sand size) [22].

The peculiarity of the PBs of Isola Bella bay is represented by the homonymous central tombolo which connects the islet to the mainland, being part of both PBs. The cliffs behind them represent elements of great natural beauty as well as the hard structure controlling the PBs. Wind data reveal that the most frequently occurring events come from the second quadrant.

Isola Bella is also a Nature Reserve, established in 1998, covering an area of 10.49 hectares. The geological landscape is composed of well-cemented limestones that form a suitable substrate for marine notch formation, indicators of former sealevel positions and colonised by a range of critical sea-level indicator organisms that have left datable remains [23].

Capo Taormina and Isola Bella are made up of dolomites and limestones, while the outcrops of Capo Sant'Andrea are composed of sandstones, conglomerates, and limestones. The north-west crag is characterized by metamorphic lithologies.

The sediments characterizing the PBs of Isola Bella bay are heterometric. They are mainly composed of coarse gravels and pebbles directly derived by the cliff dismantling, generally coarser on the south beach than on the north one.

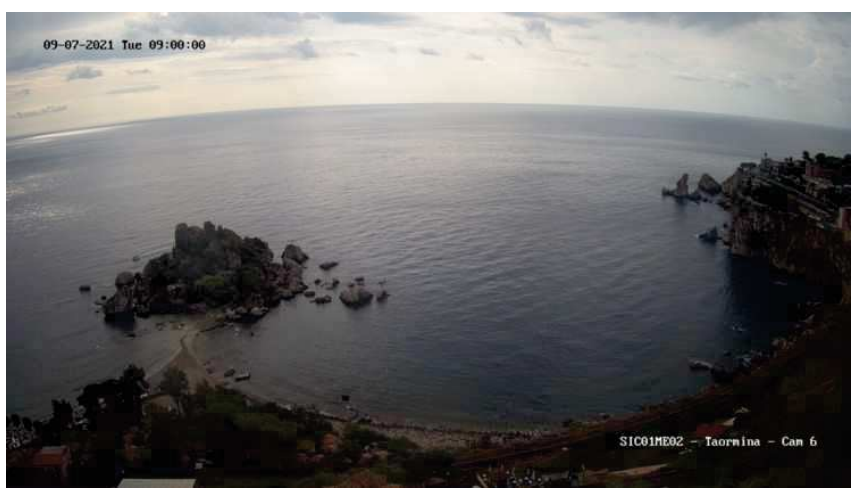

Fig. 1. The south PB and Isola Bella taken from the continuous monitoring video system, installed with the Project Interreg Italy - Malta - BESS and accessible online at http://bess.pa.ingv.it/?lang=it, accessed on 7 September 2021
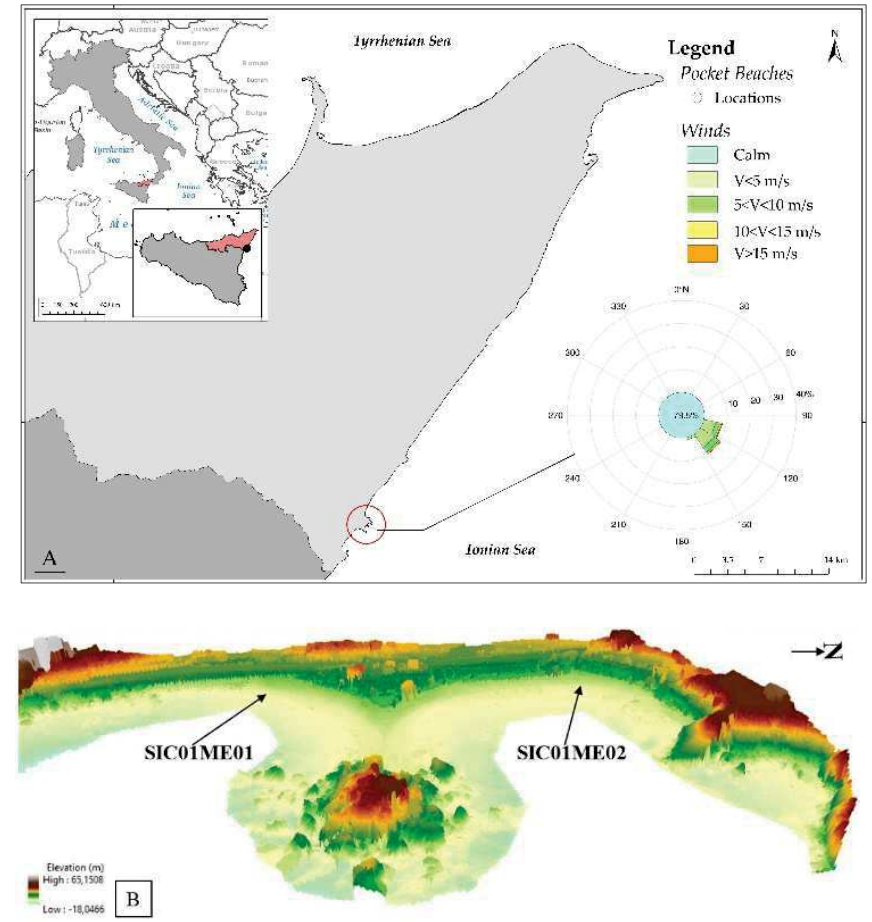

Fig. 2. Location of the pocket beaches (PBs) of Isola Bella Bay along the eastern coast of Sicily (A) and three-dimensional view (3D model) of 2 PBs (SIC01ME01, SIC01ME02 - (B).

\section{B. Methodology}

\section{1) UAV imagery acqusition:}

Two surveys were conducted in order to acquire $2 \mathrm{D}$ and 3D models of the PBs. The first was conducted on 08 April 2019 while the second one was conducted on 08 January 2020 (Tab. I) using the DJI Mavic 2 Pro UAV platform. During the flight the overlap was set to $75 \%$ (front and side) between successive frames. To improve the georeferencing precision of the acquired images, Ground Control Points (GCPs) coordinates were acquired using HiPer HR Rovers and Base station. The HiPer HR includes: 452 GNSS channel Vanguard Technology ${ }^{\mathrm{TM}}$ with Universal Tracking Channels for multifrequency tracking of multiple satellite constellations GPS, GLONASS, BeiDou, QZSS, SBAS and Galileo which allow the acquisition of the coordinates of GCPs with millimetric precision. GCPs were then used during image processing.

TABLE I. SURVEY FLIGHT CHARACTERISTICS

\begin{tabular}{|l|l|l|}
\hline \multicolumn{1}{|c|}{ Survey parameters } & \multicolumn{1}{|c|}{ First flight } & \multicolumn{1}{c|}{ Second flight } \\
\hline Date & $08 / 04 / 2019$ & $08 / 01 / 2020$ \\
\hline UAV platform & DJI Mavic 2 Pro & DJI Mavic 2 Pro \\
\hline UAV Sensor & Camera Hasselblad & $\begin{array}{l}\text { Camera Hasselblad } \\
\text { L1D-20c }\end{array}$ \\
\hline Number of flights & 4 & 4 \\
\hline Altitude & $70 \mathrm{~m}$ on the beach, 35- & $70 \mathrm{~m}$ on the beach, 35- \\
& $40 \mathrm{~m}$ on headland & $40 \mathrm{~m}$ on headland \\
\hline Duration of the survey & $1 \mathrm{~h}: 21 \mathrm{~m}: 22 \mathrm{~s}$ & $1 \mathrm{~h}: 02 \mathrm{~m}: 27 \mathrm{~s}$ \\
\hline Number of GCPs & 23 & 34 \\
\hline Number of Images & 1163 & 1081 \\
\hline RTK GPS sensor & HiPer HR GNSS & $\begin{array}{l}\text { HiPer HR GNSS } \\
\text { Receiver }\end{array}$ \\
\hline
\end{tabular}




\section{2) Imagery processing and features extraction.}

Images acquired during the two flights were processed using Pix4D Mapper software. They allowed us to generate high-resolution georeferenced orthophotos and Digital Surface Model (DSM) of the PBs of Isola Bella.

Orthophotos and DSM obtained were then processed in ArcMAP software for PBs features extraction. A computerassisted visual interpretation approach was then adopted to manually digitize, delineate, and extract the planform characteristics of the PBs (Tab. II). Triangulated Irregular Network (TIN) was computed on DSM to obtain 3D Model of the PBs. Shapefiles of geometric planform characteristics were then analyzed and presented for each PB.

TABLE II. DESCRIPTIONS OF BEACH PLANFORM CHARACTERISTICS

\begin{tabular}{|c|c|c|}
\hline Acronym & Name & $\begin{array}{c}\text { Description } \\
\end{array}$ \\
\hline Ro & $\begin{array}{l}\text { Orientation of } \\
\text { the control line }\end{array}$ & $\begin{array}{l}\text { Linear shapefile representing the } \\
\text { distance between the two headlands }\end{array}$ \\
\hline $\mathrm{a}$ & Bay indentation & $\begin{array}{ll}\text { Linear shapefile representing } & \text { the } \\
\text { orthogonal distance between } \\
\text { midpoint of Ro and S1 }\end{array}$ \\
\hline am & Maximum arrow & $\begin{array}{l}\text { Linear shapefile representing } \\
\text { maximum distance between } \\
\text { midpoint of Ro and S1 }\end{array}$ \\
\hline S1 & $\begin{array}{l}\text { Total length of } \\
\text { the shoreline }\end{array}$ & $\begin{array}{l}\text { Linear shapefile that represents the } \\
\text { internal limit of the beach }\end{array}$ \\
\hline S1e & $\begin{array}{l}\text { External bay } \\
\text { length }\end{array}$ & $\begin{array}{l}\text { Linear shapefile that represents the outer } \\
\text { limit of the beach }\end{array}$ \\
\hline S2 & $\begin{array}{l}\text { Length of the } \\
\text { embayed beach }\end{array}$ & $\begin{array}{l}\text { Linear shapefile representing the shore } \\
\text { line }\end{array}$ \\
\hline S2p & $\begin{array}{l}\text { Maximum depth } \\
\text { of the beach }\end{array}$ & $\begin{array}{l}\text { Linear shapefile indicating the beach } \\
\text { section with the longest length }\end{array}$ \\
\hline S2e & $\begin{array}{l}\text { Internal length } \\
\text { of the beach }\end{array}$ & $\begin{array}{l}\text { Linear shapefile describing the internal } \\
\text { length of the beach }\end{array}$ \\
\hline S3 & $\begin{array}{l}\text { Rope limits of } \\
\text { the beach }\end{array}$ & $\begin{array}{l}\text { Linear shapefile that joins the ends of } \\
\text { the shoreline }\end{array}$ \\
\hline $\mathrm{Sp}$ & Beach surface & $\begin{array}{l}\text { Polygonal shapefile that depicts the } \\
\text { beach area }\end{array}$ \\
\hline
\end{tabular}

\section{RESULTS AND DISCUSSIONS}

1) Beach geomorphological features.

Very high spatial resolution orthophotos and DSM obtained after the processing of imagery acquired during the first flight and the second flight (Tab. III) allowed us to view the PBs (Fig. 3) in 2 dimensions and 3 dimensions (Fig. 4). With these representations we were able to determine areas occupied by the main beaches as well as elevation variation for different areas.

TABLE III. IMAGERY PROCESSING OUT-PUT FOR THE FIRST FLIGHT

\begin{tabular}{|l|l|l|}
\hline \multicolumn{1}{|c|}{ Parameters } & \multicolumn{1}{|c|}{ First flight } & \multicolumn{1}{c|}{ Second flight } \\
\hline Average GSD & $1.81 \mathrm{~cm}$ & $1.69 \mathrm{~cm}$ \\
\hline Area covered & $0.280 \mathrm{~km}^{2}$ & $0.293 \mathrm{~km}^{2}$ \\
\hline Dataset & $\begin{array}{l}1097 \text { out of } 1163 \\
\text { images calibrated }\end{array}$ & $\begin{array}{l}1028 \text { out of 1081 } \\
\text { images calibrated }\end{array}$ \\
\hline Georeferencing & $\begin{array}{l}22 \text { GCPs with mean } \\
\text { RMS error of } 0.2 \mathrm{~m}\end{array}$ & $\begin{array}{l}18 \text { GCPs with mean } \\
\text { RMS error of } 0.012 \mathrm{~m}\end{array}$ \\
\hline Processing duration & $01 \mathrm{~h}: 38 \mathrm{~m}: 18 \mathrm{~s}$ & $2 \mathrm{~h}: 21 \mathrm{~m}: 29 \mathrm{~s}$ \\
\hline
\end{tabular}

In addition, the 2D model allows the determination of the exposure of the beach to the incident wave and the presence or absence of sand dune or cliff. The comparison of the two surveys showed that during this period only the tombolo, connecting the beaches to Isola Bella, has been affected by both erosion and accretion processes (Fig. 5).

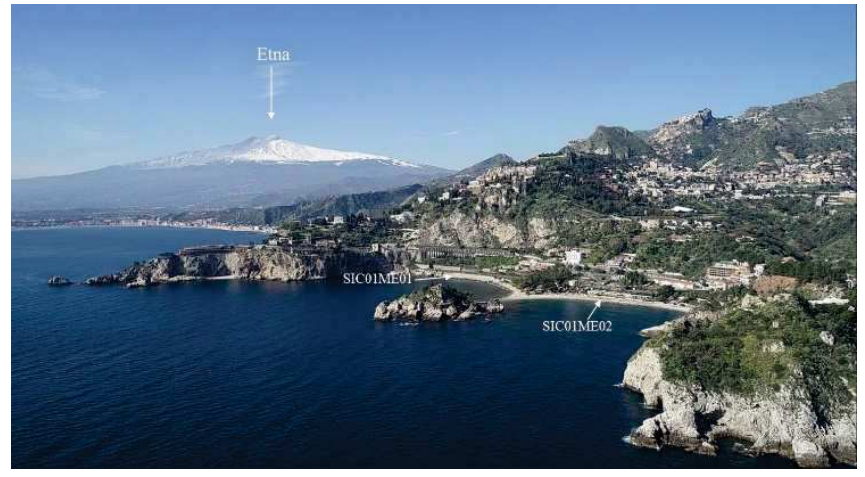

Fig. 3. UAV photograph of the PBs of Isola Bella indicating geomorphological features and Mount Etna in the background. Both the cliff and headlands protecting the bay, composed of methamorphic rocks, can be observed

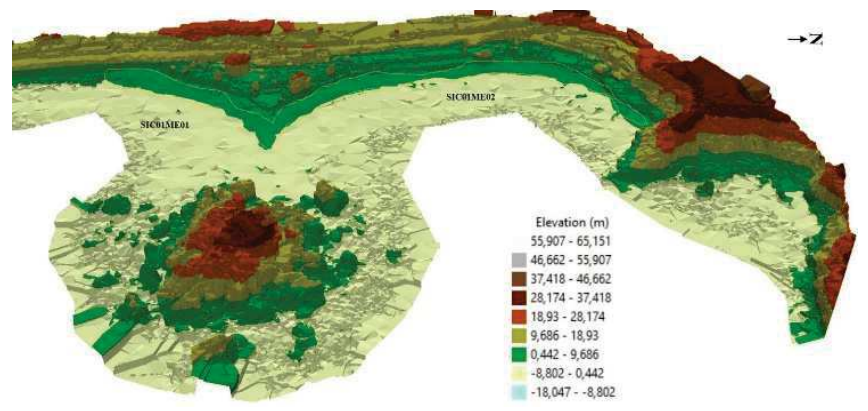

Fig. 4. TIN representing the 3D model of the PBs of Isola Bella bay.

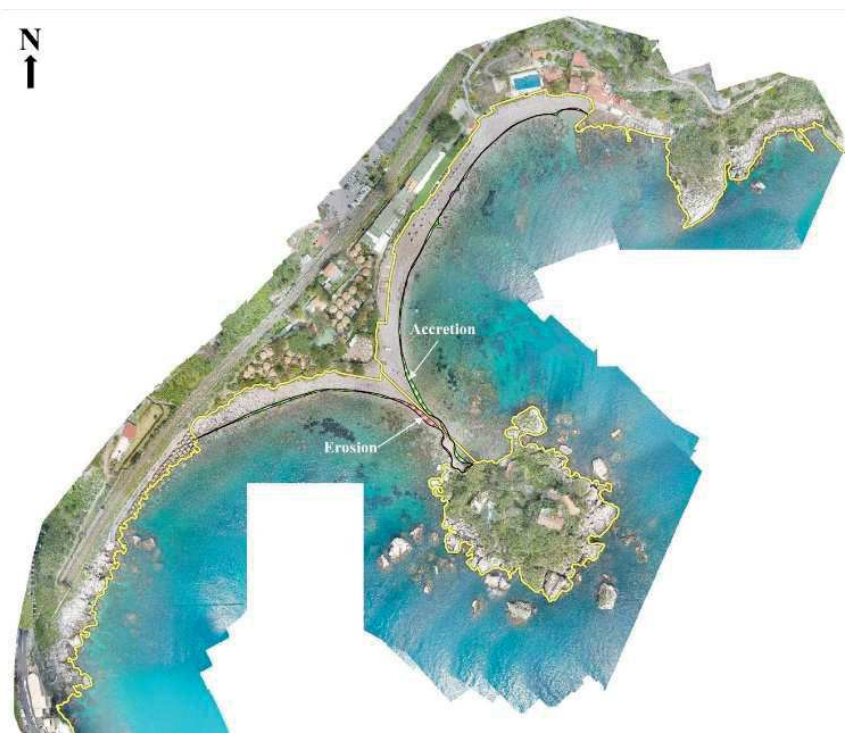

Fig. 5. Map showing areas of the beaches which experienced erosion and accretion obtained after the comparison of the two surveys.

\section{2) Beach geometric parameters.}

A computer-assisted visual interpretation approach was adopted for analysis of orthophotos and DSM. It allowed for delineation and extraction of geometric information characterizing the planview of the PBs of Isola Bella (Fig. 6). Geometric parameters analysis revealed that the two PBs are slightly different (Tab IV, Tab V). The south-western PB (SIC01ME01) has a long shoreline and long headland spacing, while the north-eastern PB has a relatively short shoreline and short headland. The comparison of the two flight surveys, for each PB (Tab IV, Tab V), revealed few morphological changes on the beach surfaces and the length 
of the shoreline. Such changes indicate the importance of considering time series comparison of beach morphology during the planform geometry analysis of PBs.

The geometric parameters of the southern PB of Isola Bella (Tab. IV) indicate a constant headland spacing (Ro), and indentation (a) of about $681.8 \mathrm{~m}$ and $221.87 \mathrm{~m}$ respectively. However, minor changes were observed on the surface of the beach ( $\mathrm{Sp}$ ) as well as the length of the shoreline (S1) with an estimation of about $9 \mathrm{~m}$, corrisponding to an increasing surface of about $80 \mathrm{~m}^{2}$.

TABLE IV. GeOMETRIC PARAMETER RESUlts OF THE SOUTHERN PB

\begin{tabular}{|c|c|c|}
\hline \multirow{2}{*}{$\begin{array}{c}\text { Geometric } \\
\text { parameters }\end{array}$} & \multicolumn{2}{|c|}{ SIC01ME01 Geometrics results } \\
\cline { 2 - 3 } & First flight (08/04/2019) & Second flight (08/01/2020) \\
\hline Ro $(\mathrm{m})$ & 681.8 & 681.8 \\
\hline $\mathrm{a}(\mathrm{m})$ & 221.87 & 221.87 \\
\hline $\mathrm{am}(\mathrm{m})$ & 472.4 & 472.4 \\
\hline $\mathrm{S} 1(\mathrm{~m})$ & 1876.64 & 1885.58 \\
\hline $\mathrm{S} 1 \mathrm{e}(\mathrm{m})$ & 1957.29 & 1966.06 \\
\hline $\mathrm{S} 2(\mathrm{~m})$ & 296.54 & 294.09 \\
\hline $\mathrm{S} 2 \mathrm{p}(\mathrm{m})$ & 19.22 & 20.91 \\
\hline $\mathrm{S} 2 \mathrm{e}(\mathrm{m})$ & 332.45 & 321.19 \\
\hline $\mathrm{S} 3(\mathrm{~m})$ & 198.52 & 198.79 \\
\hline $\mathrm{Sp}\left(\mathrm{m}^{2}\right)$ & 2751.98 & 2831.83 \\
\hline
\end{tabular}

For the northern PB (Tab. V), the same parameters were observed with headland spacing (Ro) and indentation (a) of about $441.58 \mathrm{~m}$ and $196.56 \mathrm{~m}$ respectively. Here, more significant changes were observed on the surface of the beach (Sp) as well as the length of the shoreline (S1) estimated at about $21 \mathrm{~m}$, corrisponding to an increasing surface of about $700 \mathrm{~m}^{2}$.

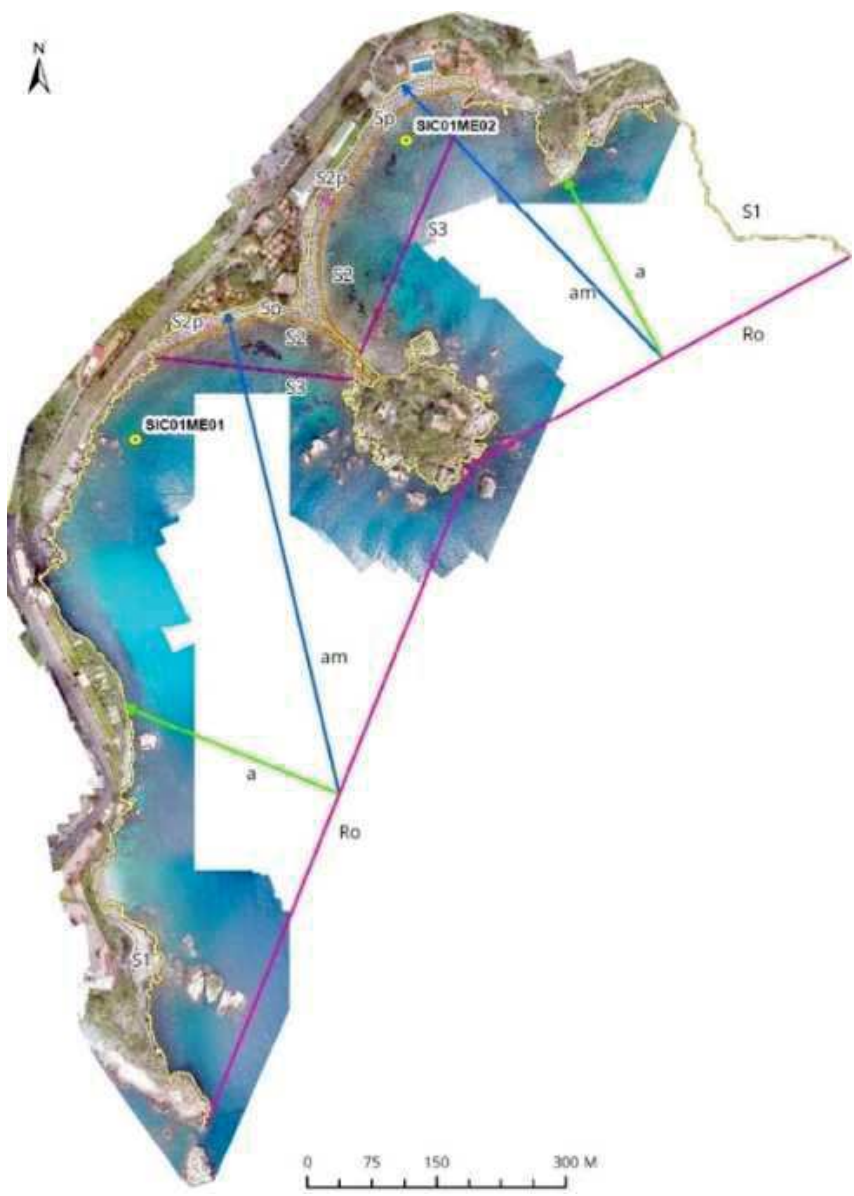

Fig. 6. Planview geometric parameters of the PBs of Isola Bella.
TABLE V. Geometric Parameter Results of THE NORTHERN PB

\begin{tabular}{|c|c|c|}
\hline \multirow{2}{*}{$\begin{array}{c}\text { Geometric } \\
\text { parameters }\end{array}$} & \multicolumn{2}{|c|}{ SIC01ME02 Geometrics results } \\
\cline { 2 - 3 } & First flight (08/04/2019) & Second flight (08/01/2020) \\
\hline Ro (m) & 441.58 & 441.58 \\
\hline $\mathrm{a}(\mathrm{m})$ & 196.56 & 196.56 \\
\hline $\mathrm{am}(\mathrm{m})$ & 362.75 & 362.75 \\
\hline $\mathrm{S} 1(\mathrm{~m})$ & 1525.6 & 1546.83 \\
\hline $\mathrm{S} 1 \mathrm{e}(\mathrm{m})$ & 1609.93 & 1624.7 \\
\hline $\mathrm{S} 2(\mathrm{~m})$ & 345.51 & 349.43 \\
\hline $\mathrm{S} 2 \mathrm{p}(\mathrm{m})$ & 20.13 & 20.86 \\
\hline $\mathrm{S} 2 \mathrm{e}(\mathrm{m})$ & 431.38 & 434.72 \\
\hline $\mathrm{S} 3(\mathrm{~m})$ & 272.73 & 272.85 \\
\hline $\mathrm{Sp}\left(\mathrm{m}^{2}\right)$ & 4960.54 & 5698.47 \\
\hline
\end{tabular}

These changes are still compatible with physiological movements due to the winds occurring in the winter season. The same functioning was also obseved from the analysis of historical maps that revealed the stability of both beaches.

\section{3) Topographic changes analysis}

By subtracting the DSM obtained during the first and the second flights, seasonal topographic variations were highlighted on the PBs of Isola Bella. Figure 7 indicates the areas of the PBs with relative sediment changes (increase, decrease, stable) within the nine months between the two flights. The shades of blue indicate erosion, while red shows accumulation, and yellow stability. Considering wave direction and grain size of the two beaches it is possible to note, on the south beach, a shifting of the finer material (coarse sand) towards the tombolo, where the littoral currents tend to accumulate it into the most protected area of Isola Bella (the reddest point); the north beach is substantially stable with prevalent internal movements (very little) in the most protected northern corner.

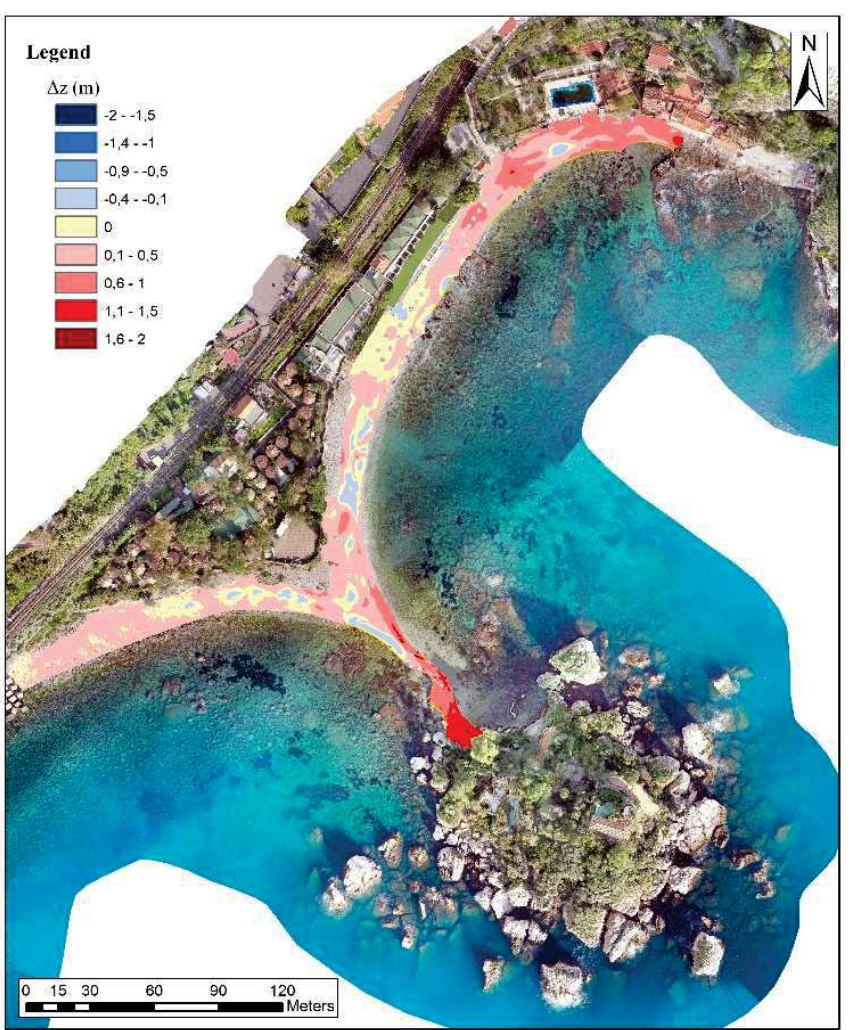

Fig. 7. Seasonal topographic variability of the PBs of Isolla Bella. 
Quantitative analyses conducted on the DSM, from these two flights, indicate a net accumulation value of about $1,847.05$ $\mathrm{m}^{3}$ (Tab. VI).

\section{TABLE VI. BeAChes' Volume estTimations}

\begin{tabular}{|c|c|}
\hline & Beach volume \\
\hline First flight & $8,159.10 \mathrm{~m}^{3}$ \\
\hline Second flight & $10,006.15 \mathrm{~m}^{3}$ \\
\hline
\end{tabular}

\section{CONCLUSION}

UAV photogrammetry and computer-assisted visual interpretation approaches were adopted in this study to map the PBs of Isola Bella located on the north-eastern coast of Sicily. Very high spatial resolution images obtained from two photogrammetry surveys show that planview analysis can be performed on highly precise dataset. Being able to o obtain 2D and 3D models of PBs allows for a better visualization of the studied area. Visual interpretation allowed for precise delineation and extraction of PB features. Such methodological approaches could be adopted to improve and perform geometric parameter analysis of other PBs.

The two Pocket Beaches of Isola Bella bay are mostly important because of their beauty, while their changes in terms of both topography and sedimentology are very small. They are a good example on of the typical dynamic of these small beaches, confined by headlands, both natural and artificial.

The changes observed on the two beaches (more important for the southern beach from the dynamic point of view than for the northern one showing the larger sediment movements) are due to their physiological evolution: we mean by this that that we did not recognize any negative effect on this resulting from human use. Nevertheless, the area is still under remote sensing control as part of the BESS Project, thanks to the installation of six cameras and an anemometric station, continuously sending data to MIFT (http://bess.pa.ingv.it/?lang=it).

\section{REFERENCES}

[1] A.D. Short, G. Masselink, "Embayed and structurally controlled beaches", In: Short, A.D. (Ed.), Handbook of Beach and Shoreface Morphodynamics. Wiley, Chichester, pp. 230 -249, 1999.

[2] D. Bowman, V. Rosas, and E. Pranzini, "Pocket beaches of Elba Island (Italy)-Planview geometry, depth of closure and sediment dispersal", Estuar. Coast. Shelf Sci., vol. 138, pp. 37-46, 2014.

[3] J.R.-C. Hsu, M. Yu, F.-C Lee and L. Benedet, "Static bay beach concept for scientists and engineers: A review", Coastal Engineering, vol. 57, pp. 76-91, 2010.

[4] 2 A.D. Short, "Role of geological inheritance in Australian beach morphodynamics", Coastal Engineering. Vol. 57, pp. 92-97, 2010.

[5] E. Pranzini, V. Rosas, N.L. Jackson, K.F. Nordstrom, "Beach Changes due to sediment delivered by streams to pocket beaches during a major flood", Geomorphology, vol. 199, pp. 36-47, 2013

[6] J.R.C. Hsu, and C. Evans, "Parabolic bay shapes and applications", Institution of Civil Engineers, Proceedings 87 Part 2. Thomas Telford, London, pp. 557-570, 1989.

[7] R. Silvester and J.R.C Hsu, "Coastal Stabilization: Innovative Concepts”, Prentice-Hall, Englewood Cliffs, NJ., pp. 578, 1993.

[8] A.H.F. Klein, L.B Filho, D.H. Schumacher, "Short-term beach rotation processes in distinct headland bay beach systems", Journal of Coastal Research, vol. 18, pp. 442-458, 2002
[9] D. Bowman, J. Guillen, L. Lopez and V. Pellegrino, "Planview Geometry and morphological characteristics of pocket beaches on the Catalan coast (Spain)", Geomorphology, vol. 108, pp. 191-199, 2009.

[10] G. Randazzo, M. Cascio, M. Fontana, F. Gregorio, S. Lanza, A. Muzirafuti, "Mapping of Sicilian Pocket Beaches Land Use/Land Cover with Sentinel-2 Imagery: A Case Study of Messina Province", Land, vol. 10(7), pp. 678, 2021, https://doi.org/10.3390/land10070678

[11] G. Randazzo, F. Italiano, A. Micallef, A. Tomasello, F.P. Cassetti, A. Zammit, S. D’Amico, O. Saliba, M. Cascio, F. Cavallaro, A. Crupi, M. Fontana, F. Gregorio, S. Lanza, E. Colica, A. Muzirafuti, "WebGIS Implementation for Dynamic Mapping and Visualization of Coastal Geospatial Data: A Case Study of BESS Project", Applied Sciences, 2021; vol. 11(17), pp. 8233, 2021, https://doi.org/10.3390/app11178233

[12] A. Muzirafuti, M. Cascio, S. Lanza, "UAV Photogrammetry-Based Mapping of Sicilian Pocket Beaches: First Approach", In Planet Care from Space; AIT Series, Trends in Earth Observation; Dessena, M.A., Melis, M.T., Eds.; Italian Society of Remote Sensing: Cagliari, Italy, 2021.

[13] G. Randazzo, S. Lanza, "Regional Plan against Coastal Erosion: A Conceptual Model for Sicily", Land, vol. 9(9), pp. 307, 2020, https://doi.org/10.3390/land9090307

[14] G. Randazzo, G. Barreca, M. Cascio, A. Crupi, M. Fontana, F. Gregorio, S. Lanza, A. Muzirafuti, "Analysis of Very High Spatial Resolution Images for Automatic Shoreline Extraction and SatelliteDerived Bathymetry Mapping", Geosciences, vol. 10(5), pp. 172, 2020, https://doi.org/10.3390/geosciences10050172

[15] A. Muzirafuti, G. Barreca, A. Crupi, G. Faina, D. Paltrinieri, S. Lanza and G. Randazzo, "The Contribution of Multispectral Satellite Image to Shallow Water Bathymetry Mapping on the Coast of Misano Adriatico, Italy". Journal Marine Science and Engineering, Vol. 8, pp. 126, 2020, doi:10.3390/jmse8020126

[16] A. Tomasello, F. P. Cassetti, A. Savona, V. Pampalone, M. Pirrotta, S. Calvo, G. Signa, C. Andolina, A. Mazzola, S. Vizzini, A. Muzirafuti, S. Lanza, G. Randazzo, "The use of very high resolution images for studying Posidonia oceanica reefs", Vie Et Milieu, vol. 70, pp. 25-35, 2020.

[17] G. Alexandrakis, A. Karditsa, N. Kampanis, "Embayment characteristics and shoreline attributes of pocket beaches in Crete", Rapp. Comm. int. Mer Médit., 41, 2016

[18] S. Manfreda, M.F. McCabe, P.E. Miller, R. Lucas, V. Pajuelo Madrigal, G. Mallinis, E. Ben Dor, D. Helman, L. Estes, G. Ciraolo, J. Müllerová, F. Tauro, MI. De Lima, J.L.M.P. De Lima, A. Maltese, F. Frances, K. Caylor, M. Kohv, M. Perks, G. Ruiz-Pérez, Z. Su, G. Vico, B. Toth, "On the Use of Unmanned Aerial Systems for Environmental Monitoring", Remote Sensing. vol. 10(4), pp. 641, 2018.

[19] D. Ventura, A. Bonifazi, M.F. Gravina, A. Belluscio, G. Ardizzone, “ Mapping and Classification of Ecologically Sensitive Marine Habitats Using Unmanned Aerial Vehicle (UAV) Imagery and Object-Based Image Analysis (OBIA)”, Remote Sensing, vol. 10(9), pp. 1331, 2018

[20] C.F. Schiaffino, M. Brignone, M. Ferrari, “Application of the parabolic bay shape equation to sand and gravel beaches on Mediterranean coasts", Coastal Engineering, vol. 59 (1), pp. 57-63, 2012.

[21] S. Simeone, L. Palombo, and G. De Falco, "Morphodynamics of a Nontidal Embayed Beach: The Case Study of Is Arutas (Western Mediterranean)", Journal of Coastal Research., vol. 29 (6a), pp. 63-71, 2013.

[22] S. Lanza, G. Randazzo, "Improvements to a Coastal Management Plan in Sicily (Italy): new approaches to borrowed sediment", managementJournal of Coastal Research, SI 64, pp. 1357 - 136, 2011.

[23] F. Antonioli, S. Kershaw, D. Rust, V. Verrubbi, "Holocene sea-level change in Sicily and its implications for tectonic models: new data from the Taormina area, northeast Sicily", Marine Geology, vol. 196, pp. 53$71,2003$. 